\title{
Teratosphaeria pseudonubilosa sp. nov., a serious Eucalyptus leaf pathogen in the Teratosphaeria nubilosa species complex
}

\author{
Guillermo Pérez • Treena I. Burgess • Bernard Slippers • \\ Angus J. Carnegie • Brenda D. Wingfield • \\ Michael J. Wingfield
}

Received: 26 March 2013 / Accepted: 23 July 2013 / Published online: 22 August 2013

(C) Australasian Plant Pathology Society Inc. 2013

\begin{abstract}
Teratosphaeria nubilosa is one of the most important pathogens of Eucalyptus in commercial plantations. A recent study has shown that the fungus, hitherto treated under this name, represents a complex of two species. Teratosphaeria pseudonubilosa sp. nov. is, therefore, described as a closely related and morphologically similar, sister species to $T$. nubilosa. T. pseudonubilosa infects leaves of commercially propagated and native E. globulus trees in forests of Victoria and Tasmania (Australia), where it is native. It has also been introduced into Western Australia and New Zealand where it causes serious defoliation of susceptible trees. A revised geographical distribution of $T$. nubilosa sensu stricto and $T$. pseudonubilosa is provided to assist in the future management of the diseases that they cause.
\end{abstract}

Keywords Mycosphaerella leaf disease · Forest pathogen · Taxonomy $\cdot$ Eucalyptus $\cdot$ Teratosphaeria nubilosa

\footnotetext{
G. Pérez $(\bowtie) \cdot$ M. J. Wingfield

Department of Microbiology and Plant Pathology, Forestry and Agricultural Biotechnology Institute (FABI), University of Pretoria, Pretoria 0002, Gauteng, South Africa

e-mail: guillermo.perez@cut.edu.uy

\section{G. Pérez}

Instituto Superior de Estudios Forestales, Centro Universitario de Tacuarembó, Universidad de la República, Montevideo, Uruguay

T. I. Burgess

CRC for Forestry, School of Veterinary and Life Sciences, Murdoch University, Perth 6150, Australia
}

T. I. Burgess $•$ B. Slippers $•$ B. D. Wingfield

Department of Genetics, Forestry and Agricultural Biotechnology

Institute (FABI), University of Pretoria, Pretoria 0002, South Africa

A. J. Carnegie

NSW Department of Primary Industries, Biosecurity NSW,

PO Box 100, Beecroft 2119, Australia
Taxonomic novelty Teratosphaeria pseudonubilosa sp. nov. G. Pérez \& Carnegie

\section{Introduction}

Species of Mycosphaerella and Teratosphaeria include some of the most important pathogens of Eucalyptus causing substantial negative impacts on plantation forestry (Carnegie 2007b; Mohammed et al. 2003; Park et al. 2000; Hunter et al. 2011). More than 150 species of Mycosphaerella and Teratosphaeria (including anamorph with asexual morph or morphs, and teleomorph with sexual morph) have been associated with Eucalyptus, causing leaf spots and stem canker diseases (Crous et al. 2009; Hunter et al. 2011). While the leaf diseases have been classically referred to as Mycosphaerella Leaf Disease (MLD) (Crous 1998), more recently, the terms "Mycosphaerella diseases" and "Teratosphaeria diseases" have been proposed to refer to those diseases, respectively caused by species of Mycosphaerella and Teratosphaeria (Hunter et al. 2011).

Teratosphaeria nubilosa (Cooke) Crous \& U. Braun is one of the most destructive pathogens among those species causing Teratosphaeria disease on Eucalyptus (Carnegie 2007b; Crous 1998; Hunter et al. 2009, 2011). Although native to Australia, this pathogen has been introduced into many countries along with its hosts (Dick 1982; Gezahgne et al. 2006; Hunter et al. 2009; Mohammed et al. 2003; Pérez et al. 2009a, 2012).

The taxonomy of T. nubilosa has been highly controversial and debated for many years (Crous et al. 1991, 2004; Crous and Wingfield 1996; Hunter et al. 2004a, 2009). Most uncertainties arise from ascospore germination patterns and other morphological features of T. nubilosa, which in Australia have differed from those observed elsewhere in the world (Carnegie 2007a; Crous et al. 2004; Crous and Wingfield 1996; Hunter et al. 2009; Park and Keane 1982b). T. nubilosa was described in 1891 as Sphaerella nubilosa on leaves of a Eucalyptus sp. 
near Melbourne, Victoria, Australia (Cooke 1891). Later, Crous et al. (2004) epitypified this species based on a collection from leaves of E. globulus collected in Briagolong, Victoria, which is $270 \mathrm{~km}$ east of Melbourne where the species was first collected and originally described.

Several phylogenetic reconstructions conducted in the past have suggested that $T$. nubilosa represents more than a single species (Crous et al. 2004, 2007; Hunter et al. 2004a, 2009). Based on DNA sequence data for three gene regions (ITS, elongation factor $1-\alpha$ and $\beta$-tubulin), some "T. nubilosa" isolates from New Zealand and others from Australia formed a clade apart from a suite of isolates collected in Australia, Spain, Kenya, South Africa and Tanzania (Crous et al. 2004; Hunter 2007). However, at that time, there was insufficient evidence to discern a new species and Hunter (2007) concluded that additional data would be required to reliably resolve this question. More recently, Pérez et al. (2012) undertook an extensive sampling for this fungus in Australia and applied new approaches as well as additional DNA sequence data to show conclusively that T. nubilosa includes two distinct and cryptic species.

The aim of this study was to undertake morphological and phylogenetic studies in order to provide a formal description of the Teratosphaeria sp. previously masked by T. nubilosa. A further aim was to use the emerging data to provide a contemporary geographical distribution for both T. nubilosa and its cryptic sister species, which is important for the future management of the diseases caused by these two fungi.

\section{Materials and methods}

Sampling and specimens examined

To study the variation on the morphological features of T. nubilosa species complex in Australia, Eucalyptus leaves with typical T. nubilosa symptoms were collected from 29 sites in New South Wales, Tasmania, Western Australia and Victoria (Pérez et al. 2012). These included leaves of Eucalyptus dunnii, $E$. globulus, E. nitens and E. nitens $\times E$. globulus hybrids in plantations, research trials and native forests. For comparative purposes, T. nubilosa leaf lesions, germinating ascospores and cultures collected in Brazil, New Zealand, South Africa and Uruguay were also studied.

\section{Phylogenetic analyses}

For phylogenetic analyses, 21 isolates were selected to represent the global intraspecific diversity previously described for T. nubilosa (Chungu et al. 2010; Crous et al. 2004; Gezahgne et al. 2006; Hunter et al. 2009) and the three native population groups identified based on microsatellite marker analyses (Pérez et al. 2012). Phylogenetic analyses included the exepitype specimen of T. nubilosa, isolate CMW 3282 (= CPC
937, = CBS 116005) from Victoria, Australia, designated by Crous et al. (2004).

All DNA sequences used in this study were used in previous phylogenetic analyses (Chungu et al. 2010; Crous et al. 2004; Gezahgne et al. 2006; Hunter et al. 2009; Pérez et al. 2009a, b, 2010, 2012) and were downloaded from GenBank (http://www. ncbi.nlm.nih.gov; Table 1). These included DNA sequence data from the internal transcribed spacers (ITS1 and ITS2) and the 5. $8 \mathrm{~S}$ gene of the rDNA operon, two portions of the $\beta$-tubulin gene region (Bt-1 and Bt-2) and 27 AFLP-derived loci.

DNA sequences were analyzed, edited and aligned in MEGA v3.1 (Kumar et al. 2004). For parsimony analyses, heuristic searches were conducted in PAUP v4.0b10 (Swofford 2002) using Tree Bisection Reconnection (TBR) as the branch swapping algorithm and the following parameters: MulTrees were 'on', starting trees were obtained via stepwise addition of 100 random replicates and remaining trees were added in single sequence fashion, MaxTrees was set at 100. Indels were coded as 0 and 1 based on absence-presence, respectively. Finally, 1000 bootstrap replicates were conducted to determine confidence levels of branching points in the phylograms. Phylograms produced by PAUP were visualized in MEGA v3.1 (Kumar et al. 2004).

Phylogenetic reconstructions were based on 29 gene regions, where each gene region was initially analysed separately. Additionally, haplotype networks were constructed pooling DNA sequence data from the 29 loci. Haplotype networks were constructed applying the software TCS v1.21 (Clement et al. 2000), which uses parsimony to infer unrooted cladograms. The connection limit was set at 100 steps and gaps were treated as a 5 th state.

To quantify the degree of exclusive ancestry of clades observed in the ITS phylogram and the haplotype network, a bootstrap consensus tree was constructed using PAUP and the parameters detailed above. This tree was uploaded into the online GSI program from http://www.geneologicalsortingindex.org. Each isolate was designated as group 1 or group 2 following the ITS phylogram and the haplotype network grouping. Using 1,000 permutations, the GSI was calculated following the methods of Cummings et al. (2008).

\section{Morphology and taxonomy}

Lesions from which the undescribed Teratosphaeria sp. was isolated were used for morphological descriptions. To obtain cross sections of pseudothecia, lesions on infected leaves were mounted in Jung Tissue Freezing Medium (Leica Microsystems AG, Wetzlar, Germany) and sections $(10 \mu \mathrm{m})$ were cut using a Leica CM 100 Freezing microtome (Leica Microsystems AG, Wetzlar, Germany). To obtain mature asci containing ascospores, mature ascomata were individually removed from the lesions using dissecting needles and mounted in lactic acid on microscope slides. To observe ascospore germination patterns 
Table 1 Teratosphaeria nubilosa and T. pseudonubilosa isolates used

\begin{tabular}{|c|c|c|c|c|c|}
\hline Country & State & Species & $\begin{array}{l}\text { CMW } \\
\text { culture no. }\end{array}$ & ITS & Beta tubulin and AFLP derived loci \\
\hline Australia & Victoria $^{\mathrm{b}}$ & T. nubilosa $a^{\mathrm{c}}$ & 3282 & HQ130795 & $\begin{array}{l}\text { HQ131261 HQ131295 HQ130829 HQ130845 } \\
\text { HQ130861 HQ130877 HQ130893 HQ130909 } \\
\text { HQ130925 HQ130941 HQ130957 HQ130973 } \\
\text { HQ130989 HQ131005 HQ131021 HQ131037 } \\
\text { HQ131053 HQ131069 HQ131085 HQ131101 } \\
\text { HQ131117 HQ131133 HQ131149 HQ131165 } \\
\text { HQ131181 HQ131197 HQ131213 HQ131229 } \\
\text { HQ131245 }\end{array}$ \\
\hline
\end{tabular}

References

\begin{tabular}{|c|c|c|c|}
\hline T. nubilosa & 30752 & HQ130800 & $\begin{array}{l}\text { HQ131266 HQ131300 HQ130834 HQ130850 } \\
\text { HQ130866 HQ130882 HQ130898 HQ130914 } \\
\text { HQ130930 HQ130946 HQ130962 HQ130978 } \\
\text { HQ130994 HQ131010 HQ131026 HQ131042 } \\
\text { HQ131058 HQ131074 HQ131090 HQ131106 } \\
\text { HQ131122 HQ131138 HQ131154 HQ131170 } \\
\text { HQ131186 HQ131202 HQ131218 HQ131234 } \\
\text { HQ131250 }\end{array}$ \\
\hline & 75 & IQ130801 & HQ131267 HQ131301 HQ130835 HQ130851 \\
\hline
\end{tabular}

Pérez et al. 2012

Crous et al. 2004;

Pérez et al. 2012

The nilosa

HQ130801

HQ131267 HQ131301 HQ130835 HQ130851

HQ130867 HQ130883 HQ130899 HQ130915

HQ130931 HQ130947 HQ130963 HQ130979

HQ130995 HQ131011 HQ131027 HQ131043

HQ131059 HQ131075 HQ131091 HQ131107

HQ131123 HQ131139 HQ131155 HQ131171

HQ131187 HQ131203 HQ131219 HQ131235 HQ131251

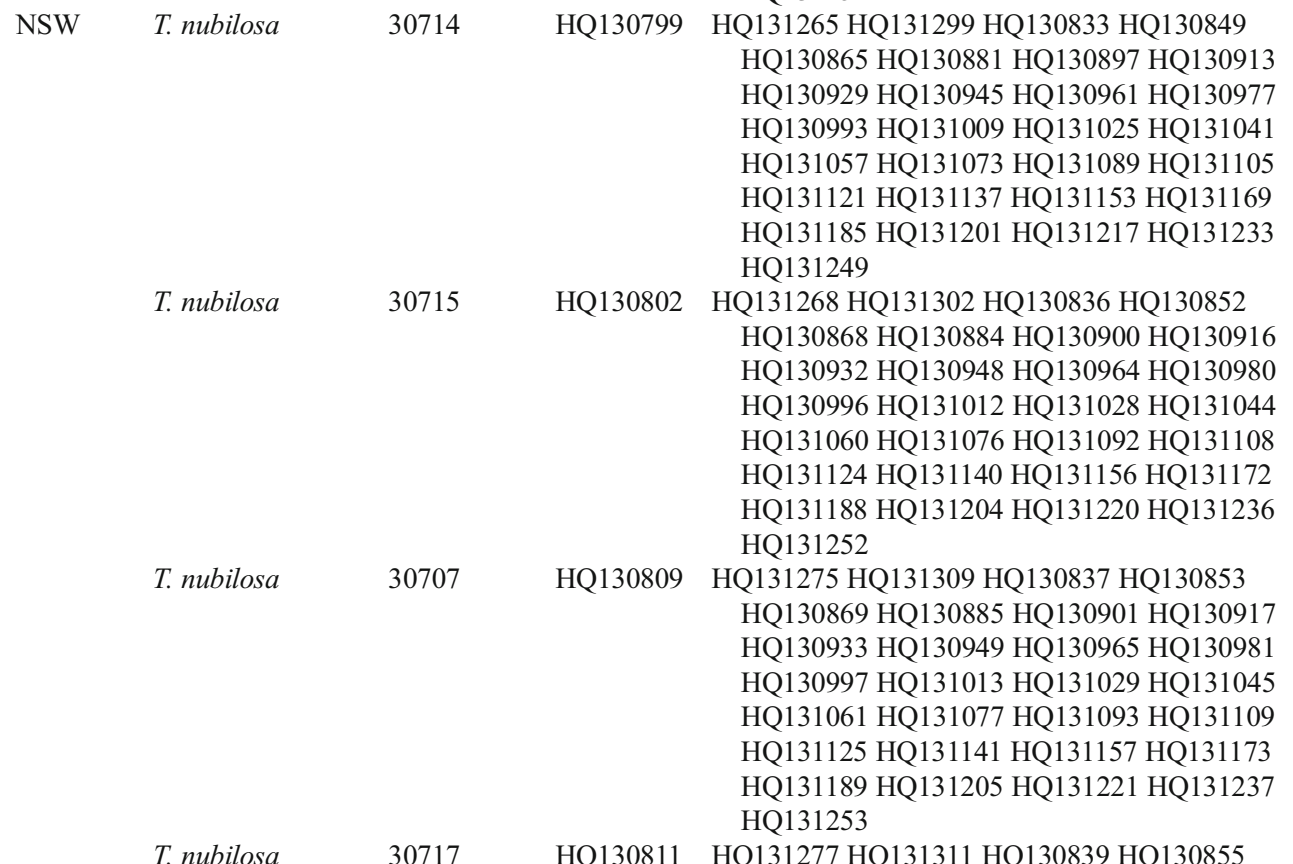

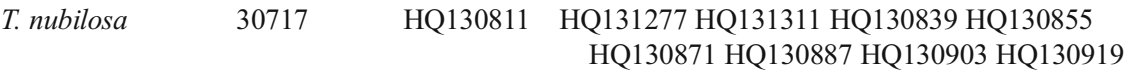
HQ130935 HQ130951 HQ130967 HQ130983 HQ130999 HQ131015 HQ131031 HQ131047 HQ131063 HQ131079 HQ131095 HQ131111 HQ131127 HQ131143 HQ131159 HQ131175 HQ131191 HQ131207 HQ131223 HQ131239 HQ131255

T. nubilosa $\quad 30709$

HQ130810 HQ131276 HQ131310 HQ130838 HQ130854 HQ130870 HQ130886 HQ130902 HQ130918 HQ130934 HQ130950 HQ130966 HQ130982 HQ130998 HQ131014 HQ131030 HQ131046 HQ131062 HQ131078 HQ131094 HQ131110

Pérez et al. 2012

Pérez et al. 2012

Pérez et al. 2012

Pérez et al. 2012

Pérez et al. 2012

Pérez et al. 2012 
Table 1 (continued)

\begin{tabular}{lllll}
\hline Country & State & Species & $\begin{array}{l}\text { CMW } \\
\text { culture no. }\end{array}$
\end{tabular}

Brazil

T. nubilosa

30900

South Africa

T. nubilosa

26014

Uruguay

T. nubilosa

30218

Ethiopia

Kenya

Spain

Portugal

Zambia

Australia

$\begin{array}{ll}\text { T. nubilosa } & 10377 \\ \text { T. nubilosa } & \text { CBS111969 } \\ \text { T. nubilosa } & \text { CPC3722 } \\ \text { T. nubilosa } & 18805 \\ \text { T. nubilosa } & 30192 \\ \text { T. pseudonubilosa } & 30745\end{array}$

T. pseudonubilosa 30750

Tasmania T.pseudonubilosa 30735

WA
T. pseudonubilosa 30723
HQ131126 HQ131142 HQ131158 HQ131174 HQ131190 HQ131206 HQ131222 HQ131238 HQ131254

HQ130798 HQ131264 HQ131298 HQ130832 HQ130848 HQ130864 HQ130880 HQ130896 HQ130912 HQ130928 HQ130944 HQ130960 HQ130976 HQ130992 HQ131008 HQ131024 HQ131040 HQ131056 HQ131072 HQ131088 HQ131104 HQ131120 HQ131136 HQ131152 HQ131168 HQ131184 HQ131200 HQ131216 HQ131232 HQ131248

HQ130796

HQ131262 HQ131296 HQ130830 HQ130846 HQ130862 HQ130878 HQ130894 HQ130910 HQ130926 HQ130942 HQ130958 HQ130974 HQ130990 HQ131006 HQ131022 HQ131038 HQ131054 HQ131070 HQ131086 HQ131102 HQ131118 HQ131134 HQ131150 HQ131166 HQ131182 HQ131198 HQ131214 HQ131230 HQ131246

HQ130797 HQ131263 HQ131297 HQ130831 HQ130847 HQ130863 HQ130879 HQ130895 HQ130911 HQ130927 HQ130943 HQ130959 HQ130975 HQ130991 HQ131007 HQ131023 HQ131039 HQ131055 HQ131071 HQ131087 HQ131103 HQ131119 HQ131135 HQ131151 HQ131167 HQ131183 HQ131199 HQ131215 HQ131231 HQ131247

AY244412

AY725563

AY725568

DQ923567

FJ805220

HQ130818

HQ131284 HQ131318 HQ130842 HQ130858 HQ130874 HQ130890 HQ130906 HQ130922 HQ130938 HQ130954 HQ130970 HQ130986 HQ131002 HQ131018 HQ131034 HQ131050 HQ131066 HQ131082 HQ131098 HQ131114 HQ131130 HQ131146 HQ131162 HQ131178 HQ131194 HQ131210 HQ131226 HQ131242 HQ131258

HQ130819 HQ131285 HQ131319 HQ130843 HQ130859 HQ130875 HQ130891 HQ130907 HQ130923 HQ130939 HQ130955 HQ130971 HQ130987 HQ131003 HQ131019 HQ131035 HQ131051 HQ131067 HQ131083 HQ131099 HQ131115 HQ131131 HQ131147 HQ131163 HQ131179 HQ131195 HQ131211 HQ131227 HQ131243 HQ131259

HQ130816 HQ131282 HQ131316 HQ130840 HQ130856 HQ130872 HQ130888 HQ130904 HQ130920 HQ130936 HQ130952 HQ130968 HQ130984 HQ131000 HQ131016 HQ131032 HQ131048 HQ131064 HQ131080 HQ131096 HQ131112 HQ131128 HQ131144 HQ131160 HQ131176 HQ131192 HQ131208 HQ131224 HQ131240 HQ131256

HQ130817 HQ131283 HQ131317 HQ130841 HQ130857 HQ130873 HQ130889 HQ130905 HQ130921 HQ130937 HQ130953 HQ130969 HQ130985
Pérez et al. 2009b

Pérez et al. 2010

Pérez et al. 2009a

Gezahgne et al. 2006

Crous et al. 2004

Crous et al. 2004

Hunter et al. 2009

Chungu et al. 2010

Pérez et al. 2012

Pérez et al. 2012

Pérez et al. 2012

Pérez et al. 2012 
Table 1 (continued)

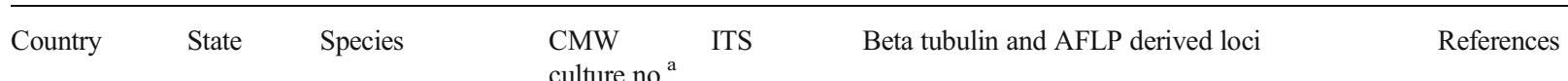

\begin{tabular}{|c|c|c|c|c|c|}
\hline \multirow{14}{*}{ New Zealand } & \multirow{12}{*}{ T. pseudonubilosa } & \multirow{12}{*}{31008} & \multirow{12}{*}{ HQ130820 } & HQ131001 HQ131017 HQ131033 HQ131049 & \multirow{12}{*}{ Pérez et al. 2012} \\
\hline & & & & HQ131065 HQ131081 HQ131097 HQ131113 & \\
\hline & & & & HQ131129 HQ131145 HQ131161 HQ131177 & \\
\hline & & & & HQ131193 HQ131209 HQ131225 HQ131241 & \\
\hline & & & & HQ131257 & \\
\hline & & & & \multirow{7}{*}{$\begin{array}{l}\text { HQ131286 HQ131320 HQ130844 HQ130860 } \\
\text { HQ130876 HQ130892 HQ130908 HQ130924 } \\
\text { HQ130940 HQ130956 HQ130972 HQ130988 } \\
\text { HQ131004 HQ131020 HQ131036 HQ131052 } \\
\text { HQ131068 HQ131084 HQ131100 HQ131116 } \\
\text { HQ131132 HQ131148 HQ131164 HQ131180 } \\
\text { HQ131196 HQ131212 HQ131228 HQ131244 } \\
\text { HQ131260 }\end{array}$} & \\
\hline & & & & & \\
\hline & & & & & \\
\hline & & & & & \\
\hline & & & & & \\
\hline & & & & & \\
\hline & & & & & \\
\hline & T. zuluensis & 17321 & DQ240207 & & Cortinas et al. 2006 \\
\hline & T. gauchensis & 17332 & DQ240218 & & Cortinas et al. 2006 \\
\hline
\end{tabular}

${ }^{\text {a }}$ CMW: Culture collection of the Forestry and Agricultural Biotechnology Institute (FABI), University of Pretoria, South Africa

${ }^{\mathrm{b}}$ Isolates from NSW were collected by A. J. Carnegie, isolates from Brazil by E. Finkenauer and isolates from New Zealand by M. J. Wingfield and remainders by G. Pérez

${ }^{\mathrm{c}}$ Ex-epitype culture and the ex-holotype cultures are shown in bold

at $24 \mathrm{~h}( \pm 0.5 \mathrm{~h})$, lesions containing mature pseudothecia were attached to the undersides of Petri dish lids as described by Crous (1998), replaced on the dishes containing Malt Extract Agar (Malt extract $20 \mathrm{~g} / 1$, Agar $20 \mathrm{~g} / \mathrm{l}$; MEA) and incubated at $25{ }^{\circ} \mathrm{C}$. Ascospore discharge was then allowed to occur for $60 \mathrm{~min}$, after which the lesions were removed from the Petri dish lids. After $24 \mathrm{~h}$, germinating ascospores were lifted from the surface of the agar and mounted in lactic acid on microscope slides. Slides were examined with a Zeiss Axioscop light microscope using differential interference contrast. Fifty measurements of all taxonomically relevant structures were made at $400 \times$ and $1000 \times$ magnification using AxioVision v4.7.2 (Carl Zeiss Imaging Solutions GmbH, Germany). Herbarium specimens representing the novel species were deposited with the National Collection of Fungi (PREM), Pretoria, South Africa.

Growth characteristics of the isolates were determined on $2 \%$ MEA. Plugs (3 $\mathrm{mm}$ diameter) of agar were cut from actively growing edges of cultures and transferred to three plates of fresh MEA for each isolate. Plates were subsequently incubated for 1 month at $25^{\circ} \mathrm{C}$ in the dark after which the colonies were measured. Colony colours were determined using the colour charts of Rayner (1970).

\section{Results}

Phylogenetic analyses

Following alignment of the ITS region for the 21 selected isolates, the DNA sequence data set included 513 characters,
508 of which were constant and 5 that were variable and parsimony-informative (Table 2). Similarly, a total of 815 characters were obtained for the $\beta$-tubulin gene region (437 and 378 for $\beta$-tubulin 1 and $\beta$-tubulin 2 , respectively), 808 of which were constant, 2 that were variable and parsimonyuninformative and 5 that were parsimony-informative (Table 2). A total of 4020 characters were obtained from all 27 AFLP derived loci (average 149 characters per locus), when a subset of 16 isolates were sequenced, showing 50 variable characters of which 47 were parsimony informative (Table 2). Therefore, where 29 loci were analyzed, a total of 62 polymorphisms were observed for the complete dataset (Table 2).

Two main groups were observed in the six ITS phylograms retained after heuristic searches. One of those phylograms $(\mathrm{CI}=$ $\mathrm{I}, \mathrm{HI}=0$ ) is presented in Fig. 1. Because the number of parsimony informative characters was low, very short branches and polytomies were observed. Identical results were observed from each of 20 anonymous loci (TN-1, TN-2, TN-3, TN-5, TN-6, TN-7, TN-9, TN-10, TN-12, TN-16, TN-18, TN-19, TN-20, TN-22, TN-24, TN-25, TN-26, TN-27, TN-28 and TN-30) (TreeBase S12689). To the contrary, in the $\beta$-tubulin, TN-14 and TN-29 phylograms, isolates CMW 30707, CMW 30709 and CMW 30717 clustered apart from the group that contained the ex-epitype specimen (CMW 3282) (TreeBase S12689). Five anonymous loci (TN-4, TN-13, TN-17, TN-21 and TN-23) showed clusters that were not consistent with either ITS or $\beta$-tubulin results (TreeBase S12689). Finally, when all 29 loci were analysed together the two main groups observed in the ITS phylogram (and the 20 anonymous loci) were also 
Table 2 DNA sequence polymorphisms contained in the ITS, $\beta$-tubulin and 27 AFLP derived loci

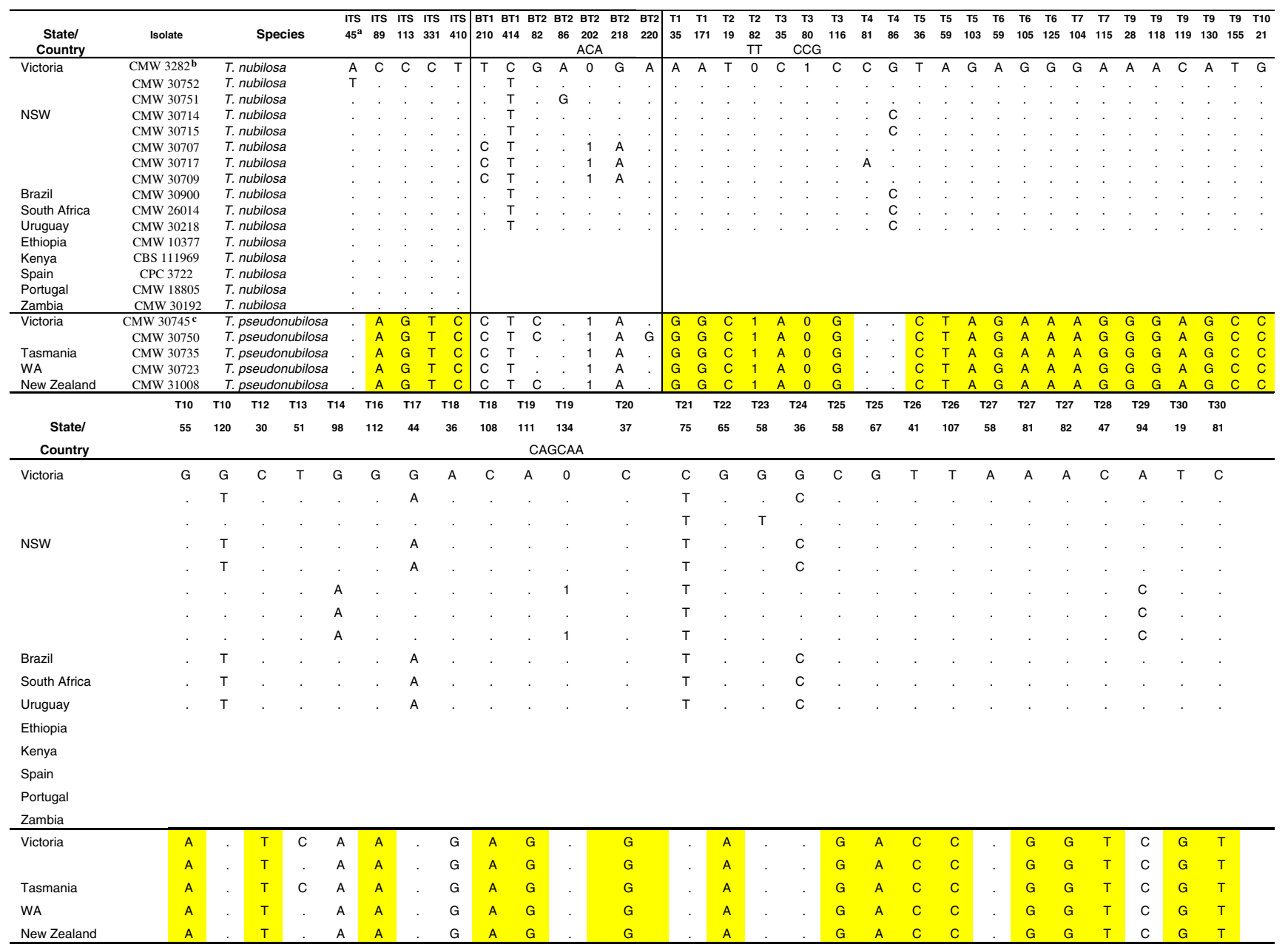

Fixed apomorphies are highlighted and indels coded as presence-absence

${ }^{\text {a }}$ Position of the substitutions in the DNA strand

${ }^{\mathrm{b}}$ T. nubilosa ex-epitype culture

${ }^{\mathrm{c}}$ T. pseudonubilosa ex-holotype culture

observed in the parsimony haplotype network (Fig. 2). Those groups of isolates were separated by 42 nucleotide changes (Fig. 2). The Genealogical Sorting Index indicates that the group that contained the ex-epitype specimen (CMW 3282) has a high level of genealogical divergence (GSI $=0.727, p<<0.01$ ) and the second group has reached monophyly (GSI $=1$, $p<<0.01)$.

\section{Taxonomy}

Results of phylogenetic analyses placed isolates analysed in the present study into two discrete phylogenetic lineages. The first lineage included the ex-epitype specimen (CMW 3282). This should consequently be treated as the lineage reflecting $T$. nubilosa sensu stricto. The second lineage included isolates from New Zealand, Western Australia, Tasmania and some isolates from Victoria and represents a novel taxon described below.
Teratosphaeria pseudonubilosa G. Pérez, \& Carnegie, sp. nov. (Figs. 3 and 4)

Etymology The name reflects the morphological similarity and the close phylogenetic relationship with T. nubilosa.

Lesions occurring on both juvenile and adult foliage of E. globulus. Leaf lesions on juvenile foliage amphigenous, circular to sub-circular, up to $15 \mathrm{~mm}$ diam., yellow to brown in colour, surrounded by a thick, raised, brown border. Single lesions frequently coalescing to form larger blotches across the leaf surfaces. On adult foliage, lesions amphigenous, angular, showing conspicuous brown border, more prominent than on juvenile foliage. Ascomata pseudothecial amphigenous on adult foliage and predominantly hypophyllous on juvenile foliage; single, evenly distributed, black, immersed to slightly erumpent, sub-stomatal, globose to slightly subglobose, 75 $110 \mu \mathrm{m}$ wide $($ average $=86 \mu \mathrm{m}) \times 70-100 \mu \mathrm{m}$ high $($ average $=$ 
Fig. 1 Consensus phylogram obtained from the ITS sequence data using parsimony and heuristic search. Branch length and bootstrap support values after 1000 randomizations are shown above and below the branching points, respectively

Fig. 2 Parsimony haplotype network for the 29 loci. Dots indicate hypothetical missing intermediate haplotypes. (asterisk) Bootstrap support value after 1000 randomizations
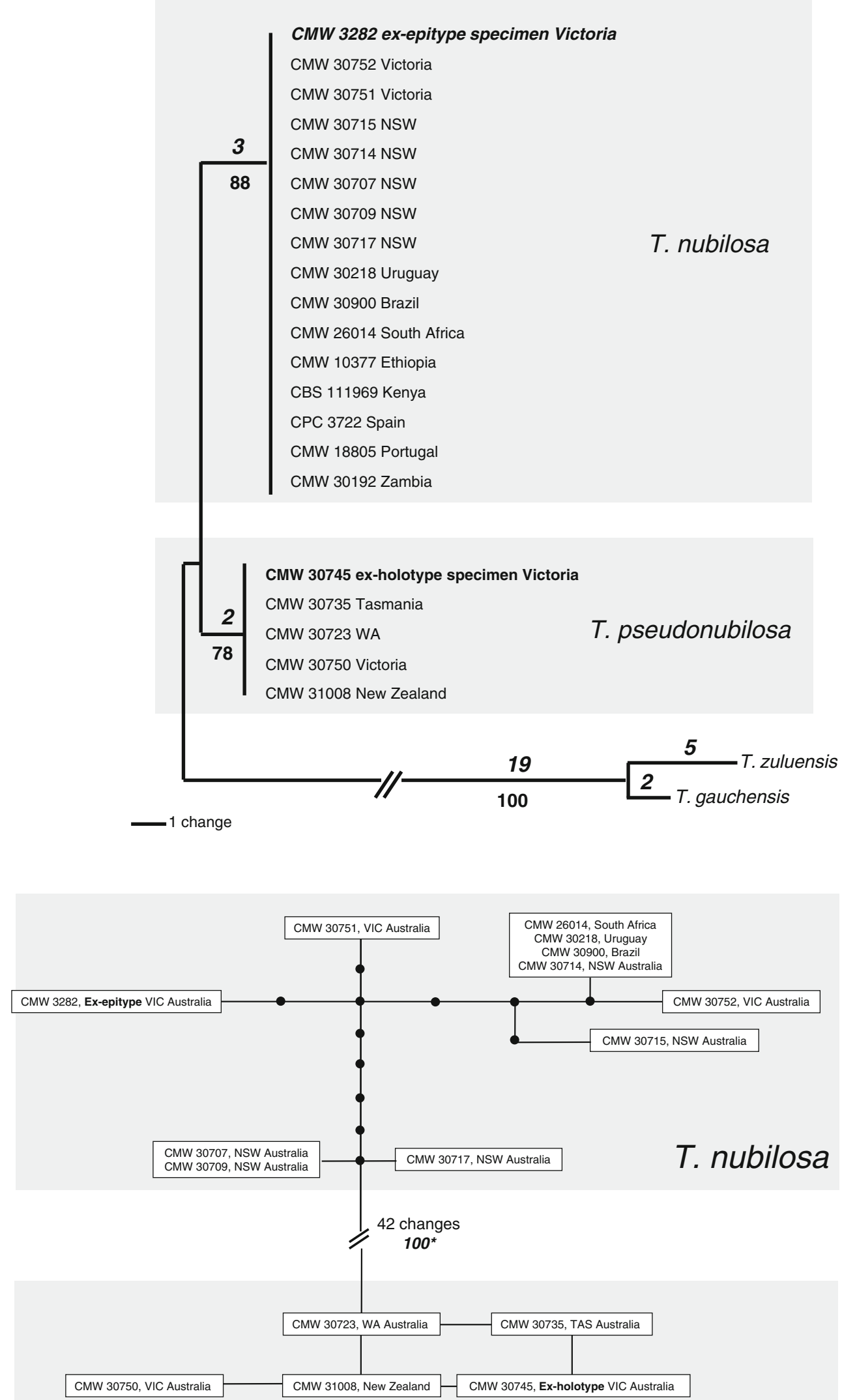

T. pseudonubilosa 
Fig. 3 Teratosphaeria pseudonubilosa lesions on juvenile (a) and adult (b) Eucalyptus globulus foliage. Morphology of $T$. pseudonubilosa colonies on MEA after 1 month at $25^{\circ} \mathrm{C}$ : (c) ex-holtype culture CMW 30745, (d) CMW 30723, and (e) CMW 30740. Scale bar $=1 \mathrm{~cm}$

Fig. 4 Teratosphaeria pseudonubilosa germinating ascospores at $24 \mathrm{~h}$ on MEA (a and $\mathbf{c}$ ) and mature asci containing ascospores (b, $\mathbf{d}$ and $\mathbf{e})$. Scale bar $=10 \mu \mathrm{m}$
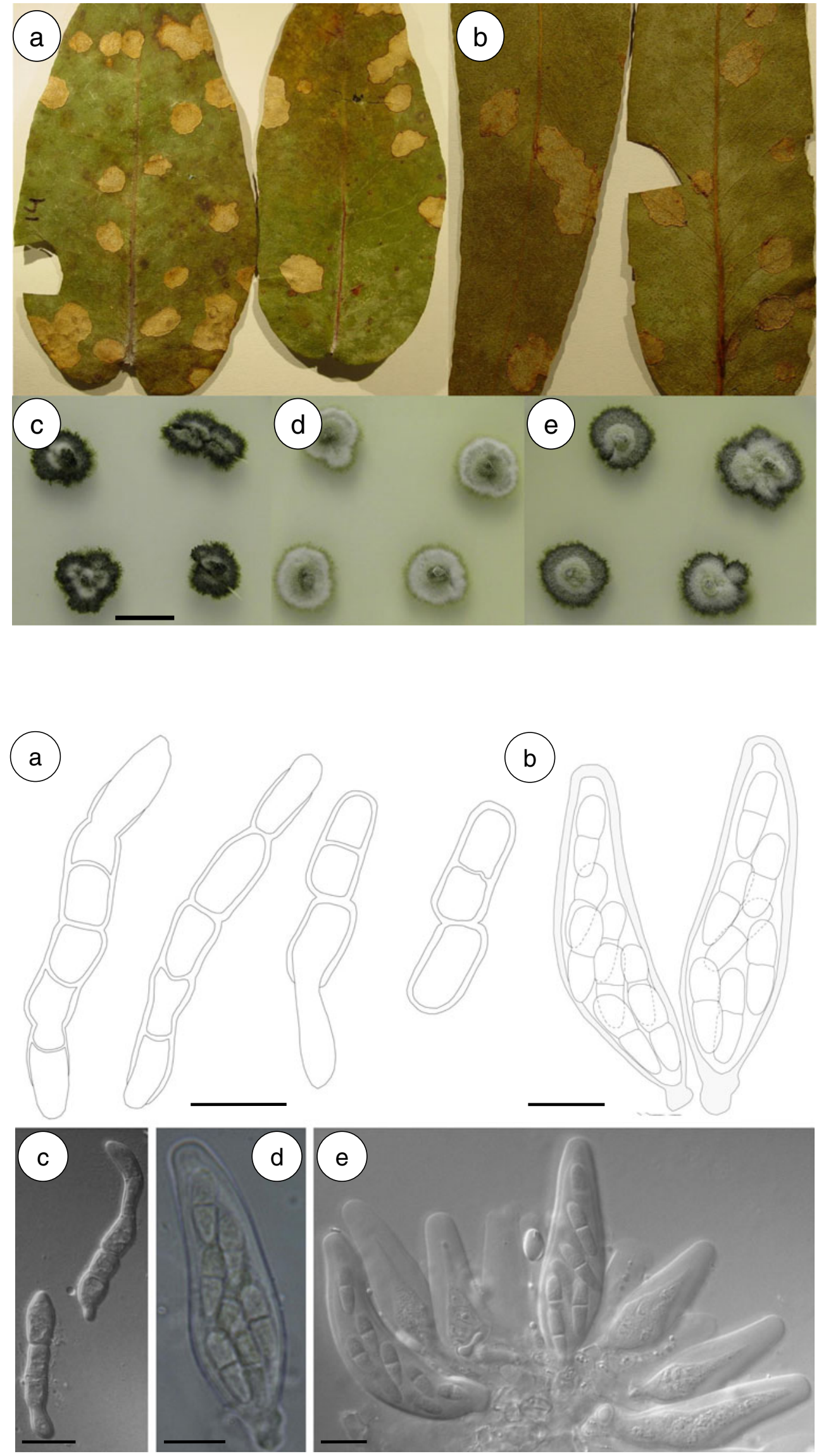
$82 \mu \mathrm{m}$ ), apical ostiole $9.5-16.3 \mu \mathrm{m}$ diam. (average $=12.3 \mu \mathrm{m}$ ), wall of 3-4 layers of medium brown textura angularis. Asci aparaphysate, fasciculate, bitunicate, subsessile, obovoid to ellipsoidal, straight to incurved, 8-spored, 47-78 $\mu \mathrm{m}$ (average $=$ $59 \mu \mathrm{m}) \times 9-16 \mu \mathrm{m}$ (average $=12 \mu \mathrm{m})$. Ascospores $2-3$ seriate, overlapping, hyaline, thin-walled, guttulate, straight, ellipsoidal, medially 1-septate, widest at the middle of the apical cell, slightly constricted at the septum, tapering towards both ends but more prominently towards the basal end, 10.6-15.5 $\mu \mathrm{m}$ (average $=$ $12.9 \mu \mathrm{m}) \times 2.3-4.2 \mu \mathrm{m}$ (average $=3.2 \mu \mathrm{m})$. Ascospore germination after $24 \mathrm{~h}$ : Ascospores distort (swell) and bend before onset of germination where the constriction at the medium septum becomes noticeable. Ascospores germinating from the polar ends of one or both cells, always with only one germ tube per cell. Germ tubes growing parallel to the long axis of the spore cell or with a slight angle. Both the germ tubes and ascospore cells developing septa during germination and ascospores not darkening during germination. Cultures on $2 \%$ MEA after 1 month at $25^{\circ} \mathrm{C}, 8.0-11.5 \mathrm{~mm}$ diam. (average $=9.9 \mathrm{~mm}$ ). Colonies varying from grey olivaceous (23'”'i) to olivaceous black (27'"'m (Rayner 1970), with scarce whitish to olive green aerial mycelium. Margins irregular but not feathery. Asexual morph not seen. Diagnosis: Four uniquely fixed nucleotide characters in the ITS gene region 89 (A), 113 (G), 331 (T), 410 (C) separate $T$. pseudonubilosa from T. nubilosa. Habitat: on living E. globulus leaves. Known distribution: native to Tasmania and Victoria, Australia, and introduced into Western Australia and New Zealand.

Specimens examined AUSTRALIA, Victoria, Kinglake $\left(37^{\circ}\right.$ $27^{\prime} \mathrm{S}, 145^{\circ} 12^{\prime} \mathrm{E}$ ), on E. globulus leaves in commercial plantations, collector Guillermo Pérez, October 2008 (PREM 60480; holotype), (cultures CMW 30745/CBS 135621; exholotype). Western Australia, Beedelup ( $34^{\circ} 22^{\prime} \mathrm{S}, 115^{\circ}$ 57'E) on E. globulus leaves in commercial plantations, collector Guillermo Pérez, August 2008, (PREM 60481; paratype), (cultures CMW 30723/CBS 135620; ex-paratype). Victoria, Briagolong ( $\left.37^{\circ} 48^{\prime} \mathrm{S}, 147^{\circ} 03^{\prime} \mathrm{E}\right)$, on E. globulus leaves in commercial plantations, collector Guillermo Pérez, October 2008 (culture CMW 30972). Tasmania, Geeveston (43 09' $\left.\mathrm{S}, 146^{\circ} 50^{\prime} \mathrm{E}\right)$ on $E$. globulus leaves in native forest, collector Guillermo Pérez, October 2008 (culture CMW 30735). NEW ZEALAND, Rotorua, on E. globulus leaves in commercial plantations, collector M. J. Wingfield, March 2009 (specimen PREM 60483, culture CMW 31008).

Notes T. pseudonubilosa is morphologically very similar to T. nubilosa and the two species cannot be reliably separated based only on morphological features. A definitive separation between these fungi is found in the four fixed nucleotide characters in the ITS gene region. Leaf lesions on E. globulus are indistinguishable for the two fungi, as are the morphological characteristics of the cultures on $2 \%$ MEA. Although there is some variation in culture growth amongst isolates of $T$. nubilosa (Hunter 2007), T. nubilosa colonies used in the present study grew slightly faster, $9.0-13.3 \mathrm{~mm}$ diam. (average $=11.3 \mathrm{~mm}$ ) than those of $T$. pseudonubilosa. The ascospore germination patterns at $24 \mathrm{~h}$ could help to distinguish T. nubilosa from T. pseudonubilosa, however, the two species would be difficult to separate using only this character.

T. pseudonubilosa ascospores germinate much more slowly than those of T. nubilosa and the germ tubes are rarely twice the length of the spores. Additionally, T. pseudonubilosa ascospore cells develop septa more often during germination and they produce germ tubes that are more numerously septate than those of T. nubilosa. The basal cells in T. pseudonubilosa usually germinate first and ascospores with un-germinated apical cells are commonly observed. Because the ascospores usually bend and the germ tubes do not always grow parallel to the long axis of the ascospore during germination, T. pseudonubilosa does not show either the typical $\mathrm{C}$ or $\mathrm{F}$ germination patterns described by Crous (1998).

\section{Discussion}

Results of this study have shown clearly that the fungus treated for many years as T. nubilosa represents a complex of two closely related species. Although this has been suspected for some time (Crous et al. 2006; Hunter 2007), definitive separation of the components of the complex has not been achieved. In this regard, it was necessary to conduct an extensive sampling of this species complex in its native range in Australia and to augment the DNA sequence data using a large number of loci. Furthermore, the outcome of this study has relied on a prior study (Pérez et al. 2012), where a large population of isolates of T. nubilosa sensu lato $(n=521)$ was subjected to an intensive population genetic analysis using eight microsatellite markers.

The discovery of a new Teratosphaeria sp. very closely related to T. nubilosa and causing MLD is significant for the eucalypt growing industry, worldwide. This is because T. nubilosa is one of the most important pathogens of Eucalyptus, particularly of $E$. globulus and $E$. nitens that are widely planted over large areas and as part of a globally important forestry industry (Hunter et al. 2009, 2011; Lundquist and Purnell 1987). T. pseudonubilosa is a sister species to T. nubilosa and in all prior studies, these two fungi have been treated collectively. It will, therefore, be necessary to reexamine all previous disease situations and tree improvement studies (e.g., Carnegie and Ades 2003; Carnegie et al. 1994, 1998) where T. nubilosa sensu lato has been implicated and to determine whether there might be differences in the host range and ecology of the two pathogens. This should not be difficult because the four fixed nucleotide characters in the ITS gene region are diagnostic and for many previous studies, sequence data are available in GenBank (Crous et al. 2004; Glen et al. 2007; Hunter 
et al. 2004b, 2009; Kularatne et al. 2004; Maxwell et al. 2001; Pérez et al. 2009a, b). Likewise, microsatellite data used on population studies (Pérez et al. 2012; Hunter et al. 2008, 2009) should also make it possible to determine which species was treated in previous studies.

Countries or continents where only T. pseudonubilosa was found include New Zealand, Western Australia and Tasmania (Crous et al. 2004; Glen et al. 2007; Hunter et al. 2009; Kularatne et al. 2004; Maxwell et al. 2001; Pérez et al. 2012). Likewise, areas where only T. nubilosa was found include New South Wales, Africa, Europe and South America (Carnegie 2007a; Crous et al. 2004; Hunter et al. 2004b, 2009; Pérez et al. 2009a, b, 2012). It is, thus, possible to conclude that all data from previous studies on T. nubilosa in New Zealand, Western Australia and Tasmania should be treated as $T$. pseudonubilosa. For New South Wales (Australia) as well as countries in Africa, Europe and South America, T. nubilosa sensu stricto was most likely the pathogen concerned in previous studies. However, in Victoria both T. nubilosa and T. pseudonubilosa co-exist in the same plantations and, therefore, it is unknown which species or whether a mixture of species is reflected in the seminal studies of Park and Keane (Park 1988a, b; Park and Keane 1982a, b).

In this study, collections of isolates included the same plantation (Briagolong, Victoria) where the epitype of T. nubilosa designated by Crous et al. (2004) had been collected. Interestingly, both T. nubilosa (CMW 30751-CMW 30753) and T. pseudonubilosa (CMW 30972) were present on leaf spots collected in this plantation. In a population analysis involving additional isolates $(n=22)$ from the same plantation, 19 were of T. nubilosa and 3 represented T. pseudonubilosa (Pérez et al. 2012). Therefore, while the ex-epitype culture of the species (CMW $3282=$ CBS 116005) corresponds to T. nubilosa, it is possible that the herbarium specimen (current epitype of $T$. nubilosa) might contain structures representing both T. nubilosa and T. pseudonubilosa. This is especially because both pathogens can be found in the same plantation, although individual leaf spots correspond to distinct colonization events (Pérez et al. 2010). Special care must be taken should future works include the study of the T. nubilosa herbarium epitype.

The present study is more extensive, in many respects, when compared with other studies describing new species of Teratosphaeria and Mycosphaerella. This detail was justified due to the great importance of T. nubilosa in plantations in many parts of the world. Thus, this study included a substantial sample (21) of isolates and these represent the diversity selected from a larger collection of 521 isolates collected in Australia and most countries where T. nubilosa and now T. pseudonubilosa occur. Phylogenetic inference and conclusions were drawn based on DNA sequence data from 29 potentially unlinked loci. This is a considerably greater number than most taxonomic studies where one or very few gene regions are considered. Population data from a previous study (Pérez et al. 2012) based on microsatellite markers were also important in defining the species delimitation.

Acknowledgments We thank the National Research Foundation (NRF), members of the Tree Protection Co-operative Programme (TPCP), the THRIP initiative of the Department of Trade and Industry and the Department of Science and Technology (DST)/NRF Centre of Excellence in Tree Health Biotechnology (CTHB), South Africa, for financial support. Katherine Taylor, Ian Smith and David Smith are thanked for their contribution in sample collections and the CRC for Forestry for financial support when G.P. was collecting specimens in Australia.

\section{References}

Carnegie AJ (2007a) Forest health condition in New South Wales, Australia, 1996-2005. I. Fungi recorded from eucalypt plantations during forest health surveys. Australas Plant Pathol 36:213-224

Carnegie AJ (2007b) Forest health condition in New South Wales, Australia, 1996-2005. II. Fungal damage recorded in eucalypt plantations during forest health surveys and their management. Australas Plant Pathol 36:225-239

Carnegie AJ, Ades PK (2003) Mycosphaerella leaf disease reduces growth of plantation-grown Eucalyptus globulus. Aust For 66:113-119

Carnegie AJ, Keane PJ, Ades PK, Smith IW (1994) Variation in susceptibility of Eucalyptus globulus provenances to Mycosphaerella leaf disease. Can J For Res 24:1751-1757

Carnegie AJ, Ades PK, Keane PJ, Smith IW (1998) Mycosphaerella diseases of juvenile foliage in a eucalypt species and provenance trial in Victoria, Australia. Aust For 61:190-194

Chungu D, Muimba-Kankolongo A, Wingfield MJ, Roux J (2010) Plantation forestry diseases in Zambia: contributing factors and management options. Ann For Sci 67:802

Clement M, Posada D, Crandall KA (2000) TCS: a computer program to estimate gene genealogies. Mol Ecol 9:1657-1659

Cooke MC (1891) Australian fungi. Grevillea 19:60-62

Cortinas MN, Crous PW, Wingfield BD, Wingfield MJ (2006) Multigene phylogenies and phenotypic characters distinguish two species within the Colletogloeopsis zuluensis complex associated with Eucalyptus stem cankers. Stud Mycol 55:133-146

Crous PW (1998) Mycosphaerella spp. and their anamorphs associated with leaf spot diseases of Eucalyptus. Mycol Mem 21:1-170

Crous PW, Wingfield MJ (1996) Species of Mycosphaerella and their anamorphs associated with leaf blotch disease of Eucalyptus in South Africa. Mycologia 88:441-458

Crous PW, Wingfield MJ, Park RF (1991) Mycosphaerella nubilosa, a synonym of M. molleriana. Mycol Res 95:628-632

Crous PW, Groenewald JZ, Mansilla PJ, Hunter GC, Wingfield MJ (2004) Phylogenetic reassessment of Mycosphaerella spp. and their anamorphs occurring on Eucalyptus. Stud Mycol 50:195-214

Crous PW, Wingfield MJ, Mansilla JP, Alfenas AC, Groenewald JZ (2006) Phylogenetic reassessment of Mycosphaerella spp. and their anamorphs occurring on Eucalyptus. II. Stud Mycol 55:99-131

Crous PW, Braun U, Groenewald JZ (2007) Mycosphaerella is polyphyletic. Stud Mycol 58:1-32

Crous PW, Groenewald JZ, Summerell BA, Wingfield BD, Wingfield MJ (2009) Co-occurring species of Teratosphaeria on Eucalyptus. Persoonia 22:38-48

Cummings MP, Neel MC, Shaw KL (2008) A genealogical approach to quantifying lineage divergence. Evolution 62:2411-2422

Dick M (1982) Leaf-inhabiting fungi of eucalypts in New Zealand. N Z J For Sci 12:525-537 
Gezahgne A, Roux J, Hunter GC, Wingfield MJ (2006) Mycosphaerella species associated with leaf disease of Eucalyptus globulus in Ethiopia. For Pathol 36:253-263

Glen M, Smith AH, Langrell SRH, Mohammed CL (2007) Development of nested polymerase chain reaction detection of Mycosphaerella spp. and its application to the study of leaf disease in Eucalyptus plantations. Phytopathology 97:132-144

Hunter GC (2007) Taxonomy, phylogeny and population biology of Mycosphaerella species occurring on Eucalyptus, Department of Microbiology and Plant Pathology. University of Pretoria, Pretoria, p 192

Hunter GC, Crous PW, Roux J, Wingfield BD, Wingfield MJ (2004a) Identification of Mycosphaerella species associated with Eucalyptus nitens leaf defoliation in South Africa. Australas Plant Pathol 33:349-355

Hunter GC, Roux J, Wingfield BD, Crous PW, Wingfield MJ (2004b) Mycosphaerella species causing leaf disease in South African Eucalyptus plantations. Mycol Res 108:672-681

Hunter GC, van der Merwe NA, Burgess TI, Carnegie AJ, Wingfield BD, Crous PW, Wingfield MJ (2008) Global movement and population biology of Mycosphaerella nubilosa infecting leaves of coldtolerant Eucalyptus globulus and E. nitens. Plant Pathol 57:235-242

Hunter GC, Crous PW, Carnegie AJ, Wingfield MJ (2009) Teratosphaeria nubilosa, a serious leaf disease pathogen of Eucalyptus spp. in native and introduced areas. Mol Plant Pathol 10:1-14

Hunter GC, Crous PW, Carnegie AJ, Burgess TI, Wingfield MJ (2011) Mycosphaerella and Teratosphaeria diseases of Eucalyptus; easily confused and with serious consequences. Fungal Divers 50:145-166

Kularatne HAGC, Lawrie AC, Barber PA, Keane PJ (2004) A specific primer PCR and RFLP assay for the rapid identification and differentiation in planta of some Mycosphaerella species associated with foliar diseases of Eucalyptus globulus. Mycol Res 108:1476-1493

Kumar S, Tamura K, Nei M (2004) MEGA3: integrated software for molecular evolutionary genetics analysis and sequence alignment. Brief Bioinform 5:150-163

Lundquist JE, Purnell RC (1987) Effects of mycosphaerella leaf spot on growth of Eucalyptus nitens. Plant Dis 71:1025-1029

Maxwell A, Hardy GESJ, Dell B (2001) First record of Mycosphaerella nubilosa in Western Australia. Australas Plant Pathol 30:65
Mohammed CL, Wardlaw T, Smith A, Pinkard E, Battaglia M, Glen M, Tommerup I, Potts B, Vaillancourt R (2003) Mycosphaerella leaf diseases of temperate eucalypts around the Southern Pacific Rim. N Z J For Sci 33:362-372

Park RF (1988a) Effect of certain host, inoculum, and environmental factors on infection of Eucalyptus species by two Mycosphaerella species. Trans Br Mycol Soc 90:221-228

Park RF (1988b) Epidemiology of Mycosphaerella nubilosa and M. cryptica on Eucalyptus spp. in South-Eastern Australia. Trans Br Mycol Soc 91:261-266

Park RF, Keane PJ (1982a) Leaf disease of Eucalyptus associated with Mycosphaerella species. Trans Br Mycol Soc 79:101-115

Park RF, Keane PJ (1982b) Three Mycosphaerella species from leaf diseases of Eucalyptus. Trans Br Mycol Soc 79:95-100

Park RF, Keane PJ, Wingfield MJ, Crous PW (2000) Fungal diseases of eucalypt foliage. In: Keane PJ, Kile GA, Podger FD, Brown BN (eds) Diseases and pathogens of eucalypts. CSIRO, Australia, pp 153-239

Pérez G, Hunter GC, Slippers B, Pérez C, Wingfield BD, Wingfield MJ (2009a) Teratosphaeria (Mycosphaerella) nubilosa, the causal agent of Mycosphaerella Leaf Disease (MLD), recently introduced into Uruguay. Eur J Plant Pathol 125:109-118

Pérez G, Slippers B, Wingfield BD, Finkenauer E, Wingfield MJ (2009b) Mycosphaerella leaf disease (MLD) outbreak on Eucalyptus globulus in Brazil caused by Teratosphaeria (Mycosphaerella) nubilosa. Phytopathol Mediterr 48:302-306

Pérez G, Slippers B, Wingfield BD, Hunter GC, Wingfield MJ (2010) Micro- and macro spatial scale analyses illustrates mixed mating strategies and extensive geneflow in populations of an invasive haploid pathogen. Mol Ecol 19:1801-1813

Pérez G, Slippers B, Wingfield MJ, Wingfield BD, Carnegie AJ, Burgess TI (2012) Cryptic species, native populations and biological invasions by a eucalypt forest pathogen. Mol Ecol 21:4452-4471

Rayner RW (1970) A mycological colour chart. Mycological Institute and British Mycological Society, Kew

Swofford DL (2002) PAUP*: phylogenetic analysis using parsimony (*and other methods). Version 4.0b10. Sinauer Associates, Sunderland 